\title{
PENETAPAN KADAR FENOL TOTAL DAN KATEKIN DAUN TEH HITAM DAN EKSTRAK ASETON TEH HITAM DARI TANAMAN CAMELLIA SINENSIS VAR. ASSAMICA
}

\author{
N. L. P. V. Paramita*, N. P. T. W. Andari, N. M. D. Andani, N. M. P. Susanti \\ Program Studi Farmasi, Fakultas Matematika dan Ilmu Pengetahuan Alam, Universitas Udayana \\ Jalan Kampus Unud-Jimbaran, Jimbaran-Bali, Indonesia 80364 \\ *Email: vidya_paramita@unud.ac.id
}

\begin{abstract}
ABSTRAK
Indonesia cukup dikenal sebagai salah satu negara yang memiliki perkebunan teh dan menggunakan teh hasil produksi sendiri. Sebagai negara penghasil teh, Indonesia telah mampu sebagai eksportir teh. Produksi teh di Indonesia yang terbanyak adalah produk teh hitam. Produk teh hitam dihasilkan dari tanaman teh Camellia sinensis Var. Assamica yang mengalami proses oksidasi enzimatis terhadap daun teh segar. Senyawa fenolik terbesar yang terkandung didalam dauh teh hitam adalah katekin, theaflavin, dan thearubigin Tujuan penelitian ini adalah untuk menetapkan kadar fenol dan kadar katekin dari produk teh hitam dan ekstrak aseton yang dihasilkan oleh perkebunan D'wan Tea (DT) dan Bali Cahaya Amertha (BCA) yang terletak di kabupaten Tabanan, Bali. Penetapan kadar fenol total dilakukan pada produk daun teh hitam dan ekstrak aseton menggunakan metode Folin-Ciocalteu dibandingkan dengan standar asam galat. Penetapan kadar katekin dilakukan pada daun teh segar (sebelum teroksidasi), produk daun teh hitam, dan ekstrak aseton dengan metode Spektrofotometri UV-Vis pada Panjang gelombang maksimum $257 \mathrm{~nm}$.. Hasil penelitian menunjukkan kadar fenol total produk daun teh hitam D'wan Tea (SDT) dan Bali Cahaya Amerta (SBCA) berturut turut 1,50 $\pm 0,02$ $\% \mathrm{mg} \mathrm{GAE} / \mathrm{g}$ dan $0,97 \pm 0,02 \% \mathrm{mg} \mathrm{GAE} / \mathrm{g}$. Hasil Kadar fenol total ekstrak aseton teh hitam D'wan Tea (EADT) yaitu 6,92 $\pm 0,12 \% \mathrm{mg} \mathrm{GAE} / \mathrm{g}$, sedangkan ekstrak aseton teh hitam Bali Cahaya Amerta (EABCA) yaitu 7,38 $\pm 0,07 \% \mathrm{mg} \mathrm{GAE} / \mathrm{g}$. Kadar katekin dari sampel daun segar D'wan Tea (SSDT), SDT, dan EADT yaitu $15,30 \pm 0,22 \% \mathrm{mg} / \mathrm{g}, 8,37 \pm 0,13 \% \mathrm{mg} / \mathrm{g}$, dan $37,45 \pm 0,74 \% \mathrm{mg} / \mathrm{g}$. Kadar katekin sampel daun segar Bali Cahaya Amerta (SSBCA), SBCA, dan EABCA yaitu 14,71 $\pm 0,28 \% \mathrm{mg} / \mathrm{g}, 15,16 \pm 0,58 \% \mathrm{mg} / \mathrm{g}$, dan $35,66 \pm 0,89 \% \mathrm{mg} / \mathrm{g}$. Kadar fenol total dari produk teh hitam DT lebih besar daripada produk teh hitam BCA. Produk teh hitam DT terlihat mengalami penurunan kadar katekin pada pengolahan. Pada pengolahan teh hitam memang diharuskan terjadi penurunan kadar katekin karena terbentuknya polimer katekin yaitu theaflavin dan thearubigin sebagai penentu kualitas teh hitam.
\end{abstract}

Kata Kunci : Camellia Sinensis, fenol total, katekin, teh hitam.

\begin{abstract}
Indonesia is quite well known as one of the countries that has tea plantations and uses its own production of tea. As a tea producing country, Indonesia has been able as a tea exporter. The most tea production in Indonesia is black tea product. Black tea products are produced from species Camellia sinensis Var. Assamica which undergoes an enzymatic oxidation process to fresh tea leaves. The most phenolic compounds contained in the black tea leaf are catechins, theaflavins, and thearubigin. The purpose of this study was to determine the phenolic total and catechin content of black tea products and acetone extracts produced by D'wan Tea (DT) and Bali Cahaya Amertha (BCA) plantations which located in Tabanan district, Bali. Determination of total phenol was carried out on black tea leaf products and acetone extract using the Folin-Ciocalteu method compared with gallic acid standards. Determination of catechin content was performed on fresh (before oxidized) tea leaves, black tea leaf products, and acetone extracts using the UV-Vis Spectrophotometry method at a maximum wavelength of $257 \mathrm{~nm}$. The results showed that total phenol content of D'wan Tea black tea products (SDT) and Bali Cahaya Amerta (SBCA) were $1.50 \pm 0.02 \% \mathrm{mg} \mathrm{GAE} / \mathrm{g}$ dan $0.97 \pm 0.02 \% \mathrm{mg}$ GAE/g, respectively. Results of the total phenol content of D'Awan Tea (EADT) black tea acetone extract was $6.92 \pm 0.12 \% \mathrm{mg}$ $\mathrm{GAE} / \mathrm{g}$, while the Bali Cahaya Amerta (EABCA) black tea acetone extract was $7.38 \pm 0.07 \% \mathrm{mg} \mathrm{GAE} / \mathrm{g}$. Catechin content from fresh leaf samples of D'wan Tea (SSDT), SDT, and EADT were $15.30 \pm 0.22 \% \mathrm{mg} / \mathrm{g}$, $8.37 \pm 0.13 \% \mathrm{mg} / \mathrm{g}$, and $37.45 \pm 0.74 \% \mathrm{mg} / \mathrm{g}$. Catechin content of fresh leaf samples of Bali Cahaya Amerta (SSBCA), SBCA, and EABCA were $14.71 \pm 0.28 \% \mathrm{mg} / \mathrm{g}, 15.16 \pm 0.58 \% \mathrm{mg} / \mathrm{g}$, and $35.66 \pm 0.89 \% \mathrm{mg} / \mathrm{g}$. Total phenol content of DT black tea products is greater than BCA black tea products. DT black tea products
\end{abstract}


appear to have decreased catechins in processing. In the processing of black tea it is necessary to decrease catechins content due to the formation of catechin polymers, namely theaflavin and thearubigin as a determinant of the quality of black tea.

Keywords: black tea, Camellia Sinensis, cathecin, total phenol.

\section{PENDAHULUAN}

Indonesia merupakan negara yang dikenal sebagai produsen dan ekportir produk minuman teh (Anjarsari, 2016). Daerah tempat budidaya tanaman teh yang dikenal dengan nama spesies Camellia sinensis tersebar di beberapa kota diantaranya Bandung, Bogor, Malang, dan salah satunya Bali. Produk teh yang diproduksi di Perkebunan teh Indonesia diantaranya; teh hitam, teh hitam CTC, teh hijau ekspor, teh hijau lokal, teh wangi (Bambang, et al, 1995). Teh hitam merupakan jenis teh yang paling banyak diproduksi di Indonesia setelah teh hijau (Anjarsari, 2016).

Tanaman teh dikenal memiliki kandungan senyawa fenol dengan senyawa katekin sebagai substansi yang paling besar. Produk teh hitam dalam proses pembuatannya mengalami proses oksidasi enzimatis yang dilakukan oleh enzim polifenol oksidase sehingga merubah jumlah kadar katekin (Anjarsari, 2016). Enzim polifenol oksidase akan merubah senyawa katekin diantaranya epicathecin, epigallocathecin, epicathecin gallate, dan epigallocathecin gallate menjadi 4 jenis senyawa theaflavin dan therubigin. Theaflavin memberi pengaruh pada astringency, brightness, dan briskness sedangkan thearubigin memberi pengaruh pada warna, kekuatan (strength), dan rasa (mouthfell) pada produk teh hitam (Hilal dan Engelhardt, 2007). Berkurangnya kadar katekin pada teh hitam menyebabkan produk teh hitam tidak lebih pahit dibandingkan teh hijau, karena rasa pahit disebabkan oleh senyawa katekin. Theaflavin dan thearubigin adalah turunan senyawa katekin yang memiliki gugus fenol sehingga dikenal sebagai senyawa polifenol. Pengolahan teh hitam meliputi tahap pelayuan, penggulungan, dan oksidasi polifenol ensimatik, pengeringan, sortasi, dan pengepakan.

Teh dikenal sebagai minuman fungsional yang bermanfaat untuk kesehatan tubuh. Kandungan kimia senyawa polifenol dikenal memiliki manfaat sebagai antioksidan.
Meskipun jumlah katekin dalam teh hitam lebih rendah dibandingkan teh hijau, namun masyarakat di pulau Sumatera lebih senng mengkonsumsi jenis teh hitam. Jumlah katekin dalam teh hitam dapat dimanfaatkan secara maksimal dengan meningkatkan frekuensi minum teh hitam. Penelitian ini bertujuan untuk menetapkan kadar senyawa polifenol dan senyawa katekin yang terdapat didalam produk teh hitam dari perkebunan lokal (Bali) yaitu D'wan Tea (DT) dan Bali Cahaya Amertha (BCA) yang terletak di kabupaten Tabanan, Bali. Penetapan kadar fenol akan dilakukan pada daun teh hitam dan ekstrak aseton teh hitam. Sedangkan, penetapan kadar katekin dilakukan pada daun teh segar (belum diolah menjadi teh hitam), daun kering teh hitam, dan ekstrak aseton teh hitam. Proses ekstraksi menggunakan pelarut aseton yang dilakukan terhadap daun kering teh hitam dengan tujuan untuk menarik senyawa polifenol yang sangat tinggi yang dimiliki oleh daun teh dibandingkan pelarut air, etanol, dan methanol (Drużyńska, et al, 2007)

\section{BAHAN DAN METODE}

\section{Bahan}

Bahan-bahan yang digunakan dalam penelitian ini adalah sampel teh hitam dari perkebunan teh DT dan perkebunan teh BCA, Desa Angseri, Kecamatan Baturiti, Kabupten Tabanan, Bali yang telah di determinasi di Fakultas Farmasi Departemen Biologi Farmasi Universitas Gadjah Mada. Pelarut aseton (Teknis), Toluene p.a (merck), standar katekin dari Henan Senyuan Biological Technologi co.ltd., standar asam galat (sigma), reagen Folin-Ciocalteu Fenol LP (merck)

\section{Peralatan}

Alat yang digunakan dalam penelitian ini adalah timbangan analitik, pengayak no 60 , oven, seperangkat alat destilasi untuk uji kadar air, rotatory evaporator, spektrofotometri UV-Vis (shimadzu). 


\section{Prosedur Kerja Pengambilan Daun Teh hitam}

Sampel daun teh hitam didapatkan dari perkebunan teh DT dan BCA. Sampel teh hitam adalah daun pucuk tanaman teh Camellia sinensis Var. Assamica yang telah mengalami tahap pengolahan yaitu pelayuan, penggilingan, oksidasi enzimatis, pengeringan.

\section{Pembuatan Serbuk Daun Teh Hitam}

Daun teh hitam diserbuk dengan menggunakan blender dan diayak dengan ayakan no 60.

\section{Pembuatan Ekstrak Aseton}

Metode pembuatan ekstrak yang digunakan adalah maserasi dengan pelarut aseton $50 \%$ dengan perbandingan 1:10. Ekstraksi dilakukan selama 3 hari, kemudian diulang kembali dengan menggunakan aseton baru sebanyak 1 kali. Ekstrak dipekatkan menggunakan rotary evaporator dan oven pada suhu $40^{\circ} \mathrm{C}$ sehingga didapat ekstrak kental.

\section{Penetapan Kadar Air Ekstrak}

Penetapan kadar air menggunakan metode destilasi. Sebanyak 5 gram ekstrak kental dan $200 \mathrm{~mL}$ toluen jenuh air dimasukkan ke dalam labu. Sejumlah toluene jenuh air juga dimasukkan kedalam tabung penerima melalui pendingin sampai leher alat penampung. Labu dipanaskan selama 15 menit. Jumlah volume air dalam alat penampung dihitung sebagai $\%$ kadar air (Kemenkes RI, 2011).

\section{Penetapan Kadar Fenol}

a. Pembuatan larutan standar asam galat Larutan standar asam galat $1 \mathrm{mg} / \mathrm{mL}$ dibuat dengan menimbang $10 \mathrm{mg}$ asam galat dilarutkan dalam metanol p.a hingga volume $10 \mathrm{~mL}$. Selanjutnya, dibuat seri konsentrasi larutan standar dengan melakukan pengenceran sampai didapatkan konsentrasi larutan standar beturut - turut $2 ; 4 ; 8 ; 12 ; 16 ; 20 \mathrm{ppm}$ $(\mu \mathrm{g} / \mathrm{mL})$.

b. Pembuatan larutan uji serbuk

Larutan uji serbuk dalam pengukuran fenol adalah serbuk teh hitam DT (SDT) dan serbuk teh hitam BCA (SBCA). Larutan uji SDT dan SBCA dibuat dengan cara menimbang $200 \mathrm{mg}$ serbuk simplisia, dilarutkan dalam metanol p.a hingga $10 \mathrm{~mL}$. Larutan digojog hingga homogen dan dimasukkan ke dalam tabung reaksi. Campuran larutan uji serbuk divortex selama 2 menit kemudian disaring. Dari larutan tersebut dipipet sebanyak 0,005 $\mathrm{mL}$ ditambahkan $0,395 \mathrm{~mL}$ metanol p.a.

c. Pembuatan larutan uji ekstrak

Larutan uji ekstrak dalam pengukuran fenol adalah ekstrak aseton DT (EADT) dan ekstrak aseton BCA (EABCA). Larutan uji EADT dan EABCA dibuat dengan menimbang $10 \mathrm{mg}$ ekstrak dilarutkan dalam metanol p.a hingga 10 $\mathrm{mL}$. Larutan digojog hingga homogen dan dimasukkan ke dalam tabung reaksi. Campuran larutan uji ekstrak divortex selama 2 menit kemudian disaring. Dari larutan tersebut dipipet sebanyak $0.02 \mathrm{~mL}$ ditambahkan $0.38 \mathrm{~mL}$ metanol p.a.

d. Pengukuran kadar fenol larutan standar, larutan uji SDT, SBCA, EADT, EABCA.

Masing - masing larutan dipipet sebanyak $0.4 \mathrm{~mL}$ ditambahkan $0.4 \mathrm{~mL}$ pereaksi Folin Ciocalteu Fenol LP dan $4.2 \mathrm{~mL}$ $\mathrm{Na} 2 \mathrm{CO} 3$ di dalam tabung reaksi. Campuran divortex selama 2 menit, diinkubasi selama 30 menit. Serapan masing - masing larutan diukur pada Panjang gelombang maksimum $760 \mathrm{~nm}$. Selanjutnya, dibuat kurva kalibrasi dengan membuat hubungan antara konsentrasi (x) dan absorbansi (y) larutan seri. Dihitung kadar fenol total sebagai berikut:

$$
\begin{aligned}
& \qquad \mathrm{x}=\frac{\mathrm{y}-\mathrm{a}}{\mathrm{b}} \\
& \text { \% Kadar fenol total }(\mathrm{EAG})=\frac{\mathrm{x}}{\mathrm{xs}} \times \mathrm{f} \times 100 \% \\
& \text { Keterangan: } \\
& \mathrm{y}=\text { absorbansi } \\
& \mathrm{x}=\text { konsentrasi } \\
& \text { xs = konsentrasi sampel } \\
& \mathrm{f}=\text { faktor pengenceran }
\end{aligned}
$$

\section{Penetapan Kadar Katekin}

a. Pembuatan larutan standar katekin

Larutan standar katekin $1 \mathrm{mg} / \mathrm{mL}$ dibuat dengan menimbang $100 \mathrm{mg}$ standar katekin dilarutkan dalam $100 \mathrm{~mL}$ metanol p.a. Selanjutnya, dibuat seri konsentrasi larutan 
standar dengan melakukan pengenceran sampai didapatkan konsentrasi larutan standar berturut turut $5 ; 10 ; 15 ; 20 ; 25 \mathrm{ppm}$ $(\mu \mathrm{g} / \mathrm{mL})$.

b. Pembuatan larutan uji serbuk

Larutan uji serbuk dalam pengukuran katekin adalah serbuk segar teh DT (SSDT), serbuk segar teh BCA (SSBCA), serbuk teh hitam DT (SDT) dan serbuk teh hitam BCA (SBCA). Larutan uji SSDT, SSBCA, SDT dan SBCA dibuat dengan cara menimbang $100 \mathrm{mg}$ serbuk dilarutkan dalam 10 mL metanol p.a. Larutan Digojog hingga homogen, dipindahkan ke botol vial dan disonikasi selama 30 menit kemudian disaring. Selanjutnya, dipipet sebanyak $0,1 \mathrm{~mL}$ ditambahkan metanol p.a sampai $10 \mathrm{~mL}$.

c. Pembuatan larutan uji ekstrak

Larutan uji ekstrak dalam pengukuran katekin adalah ekstrak aseton DT (EADT) dan ekstrak aseton BCA (EABCA). Larutan uji EADT dan EABCA dibuat dengan cara menimbang $10 \mathrm{mg}$ ekstrak dilarutkan dalam $10 \mathrm{~mL}$ metanol p.a. Larutan Digojog hingga homogen, dipindahkan ke botol vial dan disonikasi selama 30 menit kemudian disaring. Selanjutnya, dipipet sebanyak $0,1 \mathrm{~mL}$ ditambahkan metanol p.a sampai $5 \mathrm{~mL}$.

d. Pengukuran kadar katekin larutan standar, SSDT, SSBCA, SDT, SBCA, EADT, EABCA

Serapan masing - masing larutan diukur pada panjang gelombang maksimum 257 nm. Selanjutnya, dibuat kurva kalibrasi dengan membuat hubungan antara konsentrasi (x) dan absorbansi (y) larutan seri. Dihitung kadar katekin sebagai berikut:

$$
\begin{gathered}
\mathrm{x}=\frac{\mathrm{y}-\mathrm{a}}{\mathrm{b}} \\
\% \text { Kadar total katekin }=\frac{\mathrm{x}}{\mathrm{xz}} \times \text { f } \mathrm{x} 100 \%
\end{gathered}
$$

Keterangan:

$$
\begin{aligned}
& y=\text { absorbansi } \\
& x=\text { konsentrasi } \\
& x s=\text { konsentrasi sampel } \\
& f=\text { faktor pengenceran }
\end{aligned}
$$

\section{HASIL DAN PEMBAHASAN}

Minuman teh hitam menjadi kegemaran masyarakat Indonesia karena rasanya yang tidak pahit jika dibandingkan teh hijau. Tahap pembuatan teh hitam diawali tahap pertama yaitu pelayuan. Pada tahap ini daun teh mengalami perubahan senyawa senyawa kimia dan menurunnya kandungan air. Warna daun berubah menjadi hijau kekuningan, dengan bentuk daun layu (tidak remuk ketika di genggam). Tahap kedua yaitu penggilingan yang merupakan awal mula terjadinya oksimatis (oksidasi enzimatis). Proses penggilingan yang berlangsung selama 90 - 120 menit menyebabkan dinding sel daun teh menjadi rusak (Direktorat pengolahan dan pemasaran perkebunan, 2017), sehingga menyebabkan enzim polifenol oksidase yang terletak di sitoplasma dan katekin yang terletak di dalam vakuola dapat bertemu, dengan adanya oksigen didalam lingkungan maka terjadilah reaksi oksidasi polifenol katekin (flavan-3-ol) menjadi senyawa polimer theaflavin dan thearubigin (Pou, 2016; Anjarsari, 2016). Kedua senyawa ini yang mempengaruhi warna, rasa maupun aroma seduhan teh hitam. Tahap ketiga adalah pengeringan yang bertujuan untuk menghentikan reaksi oksidasi. Proses ini menyebabkan kadar air teh turun menjadi 2.4 $3.5 \%$. Tahap selanjutnya adalah sortasi dan grading untuk mendapatkan serbuk teh hitam dengan mutu yang telah ditetapkan secara nasional (Direktorat pengolahan dan pemasaran perkebunan, 2017).

Dauh teh hitam yang didapatkan dari perkebutan DT dan BCA di kecilkan ukuran partikel sampai semua sebuk lolos pada ayakan no 60. Tujuan pengecilan ukuran partikel untuk meningkatkan luas permukaan parikel dengan tujuan agar kandungan kimia didalam sel tanaman dapat tersari dengan maksimal. Pelarut ekstraksi pada penelitian ini adalah aseton. Penelitian Drużyńska, 2007 melaporkan diantara 4 jenis pelarut yaitu aseton $80 \%$, metanol $80 \%$, etanol $80 \%$, dan air yang digunakan, pelarut aseton mampu menarik kandungan polifenol lebih banyak yaitu $12,36 \mathrm{~g} / 100 \mathrm{~g}$ serbuk kering teh dalam waktu 1 jam sedangkan perolehan kadar polifenol dalam air, metanol, dan air berturut turut 9,$21 ; 7,09$; dan $6,85 \mathrm{~g} / 100 \mathrm{~g}$ serbuk kering teh dalam 1 jam ekstraksi. Bahkan, 
kadar polifenol yang diperoleh dengan pelarut aseton $80 \%$ dalam waktu 15 menit ekstraksi masih lebih tinggi yaitu $9.8 \mathrm{~g} / 100 \mathrm{~g}$ serbuk kering teh. Perva-Uzunalic, et al, 2006 menyatakan bahwa pelarut aseton 50\% memiliki effisiensi ekstraksi katekin yang lebih tinggi yaitu 99,3\% dibandingkan pelarut aseton $80 \%$ sebesar $95,8 \%$. Karena tanaman teh kandungan utama senyawa fenol adalah katekin, dan dalam teh hitam senyawa theflavin dan thearubigin adalah senyawa polimer katekin maka peneliti memilih pelarut ekstraksi adalah aseton 50\%. Dari $100 \mathrm{~g}$ serbuk teh hitam, jumlah rendemen ekstrak dari kedua perkebunan teh memperoleh jumlah ekstrak yang tidak jauh berbeda yaitu EADT 32,522 g dan EABCA 32,552 g.

Direktorat pengolahan dan pemasaran perkebunan, 2017, Pou, 2016, Choundary and shekon, 2011; Kunle, et al, 2012

Dalam upaya menjamin mutu dari bahan baku ekstrak, maka dilakukan penetapan kadar air. Penetapan kadar air bertujuan untuk mengurangi kesalahan saat menghitung berat sebenarnya ekstrak ketika digunakan sebagai bahan baku obat tradisional. Selain itu jumlah air akan mempengaruhi stabilitas dari ekstrak oleh karena reaksi enzimatis yang masih dapat terjadi dan tumbuhnya mikroorganisme yang dapat mempengaruhi kandungan kimia didalam ekstrak (Choundary and shekon, 2011; Kunle, et al, 2012). Pada penelitian ini dilakukan pengeringan ekstrak dengan bantuan rotrary evaporator dan oven suhu $40{ }^{\circ} \mathrm{C}$ selama 4 hari. Nilai kadar air yang diperoleh tertera di dalam tabel 1. Nilai tersebut telah memenuhi syarat nilai kadar air ekstrak etanol Camellia sinensis yang teertulis di dalam Farmakope Herbal Indonesia (FHI).

Tabel 1. Hasil penetapan kadar air Ekstrak teh hitam

\begin{tabular}{lll}
\hline Penetapan & $\begin{array}{l}\text { Referensi } \\
\text { mutu teh } \\
\text { dalam }\end{array}$ & Hasil penelitian \\
& FHI & \\
\hline \multicolumn{3}{l}{ Uji kadar air } \\
EADT & $16 \% \mathrm{~b} / \mathrm{b}$ & $10,96 \pm 0,02 \% \mathrm{~b} / \mathrm{b}$ \\
EABCA & $16 \% \mathrm{~b} / \mathrm{b}$ & $8,94 \pm 0.2 \% \mathrm{~b} / \mathrm{b}$ \\
\hline
\end{tabular}

Kandungan kimia tanaman teh akan bervariasi dipengaruhi oleh iklim, varietas teh, dan umur daun teh. Teh diketahui memiliki kandungan kimia diantaranya tannin atau senyawa fenolik (5-27 \%) yang terdiri dari katekin (flavanol) dan asam galat. Pada daun segar tanaman teh diketahui memiliki $36 \%$ senyawa polifenol, dimana kandungan katekin berada pada persentase $48-55 \%$ dari seluruh total polifenol. Komponen kimia lainnya yang ada didalam teh adalah lemak (4-16\%), asam amino, sterol, vitamin, mineral, protein, triterpenoid dan senyawa lainnya (PervaUzunalic, et al 2006). Membagi daun teh menjadi bagian - bagian yang kecil pada pembuatan teh hitam akan menyebabkan terjadinya reaksi oksidasi enzimatis (oksomatis), dimana sitoplasmik polifenol oksidase akan mengoksidasi katekin (flavan-3ol) yang ada di vakuola. Proses ini dikenal sebagai oksidasi atau fermentasi yang merupakan proses polimerisasi monomer flavan-3-ol membentuk theaflavin yang memberi warna kuning dan thearubigin yang memberi warna merah kecoklatan (Balittri, 2013; Anjarsari, 2016). Jenis senyawa theaflavin yang terbentuk dipengaruhi oleh bentuk senyawa precursornya yaitu katekin. Terdapat empat jenis senyawa theafavin yang telah berhasil diidentifikasi yaitu theaflavin, theaflavin-3-gallate, theaflavin- 3' gallate, dan theaflavin 3,3' gallate (Anjarsari, 2016). Sedangkan jenis senyawa thearubigin belum dapat diidentifikasi sampai saat ini (Whitehead and Temple, 1992 dalam Anjarsari, 2016). Pada penelitian ini, dilakukan penetapan kadar fenol terhadap serbuk teh hitam dan ekstrak aseton dari teh hitam dengan tujuan untuk mengetahui seberapa besar kandungan fenol dalam teh hitam yang dihasilkan oleh dua perkebunan teh di Bali.

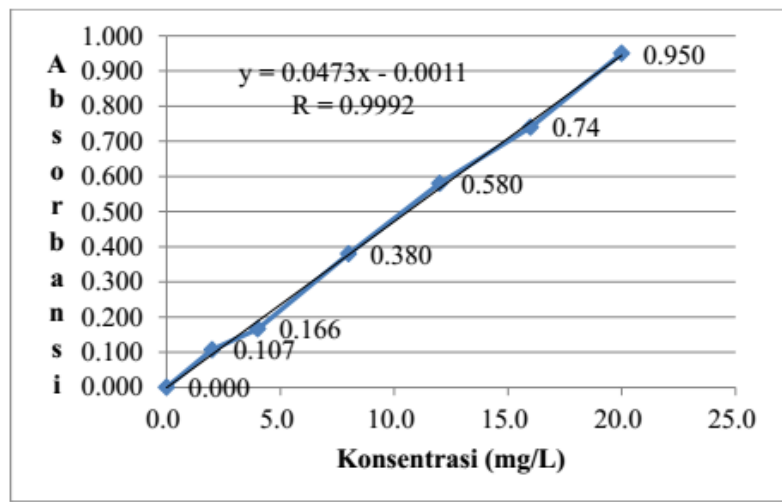

Gambar 1. Kurva kalibrasi larutan standar asam galat. 
Pada penetapan kadar fenol, dibuatlah seri larutan standar agar memperoleh persamaan regresi yang selanjutnya digunakan untuk menetapkan kadar fenol dalam sampel. Dari hasil pengukuran absorbansi larutan standar pada Panjang gelombang maksimum $760 \mathrm{~nm}$ diperoleh persamaan regresi linier dan kurva kalibrasi (hubungan antara konsentrasi (x) dan absorbansi (y) dari seri larutan standar) yang ditunjukkan pada gambar 1.

Setelah dilakukan pengenceran sampel uji, kemudian dilakukan pengukuran absorbansi dari sampel untuk memperoleh kadar fenol dalam sampel. Hasil penelitian kadar fenol ditunjukkan pada tabel 2.

Tabel 2. Kadar Fenol Total Teh Hitam

\begin{tabular}{ll}
\hline Sampel & $\begin{array}{l}\text { Kadar Fenol total } \\
\boldsymbol{\%} \mathbf{b} / \mathbf{b}(\mathbf{m g} \text { GAE/g) } \pm \mathbf{S D}\end{array}$ \\
\hline SDT & $1,50 \pm 0.02$ \\
SBCA & $0,97 \pm 0.02$ \\
EADT & $6,92 \pm 0.12$ \\
EABCA & $7,38 \pm 0.07$ \\
\hline
\end{tabular}

Berdasarkan hasil penelitian didapatkan bahwa nilai kadar fenol total serbuk teh hitam perkebunan DT lebih tinggi dibandingkan nilai kadar fenol dari perkebunan BCA. Sedangkan nilai kadar fenol ekstrak kedua perkebunan tidak berbeda signifikan. Penggunaan pelarut aseton mampu menarik senyawa fenolik sekitar $\pm 7 \%$. Mengingat penggunaan teh hitam di masyarakat biasanya diolah dengan cara membuat seduhan teh dari serbuk teh maka teh hitam dari perkebunan DT dapat dipilih karena memiliki kandungan fenolik yang lebih baik. Senyawa fenolik dikenal memiliki aktivitas antioksidan. Senyawa fenolik dalam teh hitam diantaranya, senyawa flavanol yaitu katekin, polimer katekin (theaflavin dan thearubigin), dan senyawa flavanol lainnya kaempferol, mirisetin, kuersetin.

Hasil penelitian penetapan kadar senyawa katekin dapat dilihat pada Tabel 3 . Pada penelitian ini dilakukan senyawa katekin dari daun segar (belum diolah menjadi teh hitam), serbuk teh hitam, dan ekstrak aseton teh hitam untuk melihat kualitas produk teh hitam yang kualitasnya ditentukan dari adanya penurunan kadar katekin. Pada penetapan kadar katekin, dibuatlah seri larutan standar katekin agar memperoleh persamaan regresi yang selanjutnya digunakan untuk menetapkan kadar katekin dalam sampel. Hasil scanning panjang gelombang dari $200-400 \mathrm{~nm}$ didapatkan Panjang gelombang maksimum pengukuran katekin yaitu $257 \mathrm{~nm}$. Dari hasil pengukuran absorbansi larutan standar pada diperoleh persamaan regresi linier dan kurva kalibrasi (hubungan antara konsentrasi (x) dan absorbansi (y) dari seri larutan standar) yang ditunjukkan pada gambar 2 .

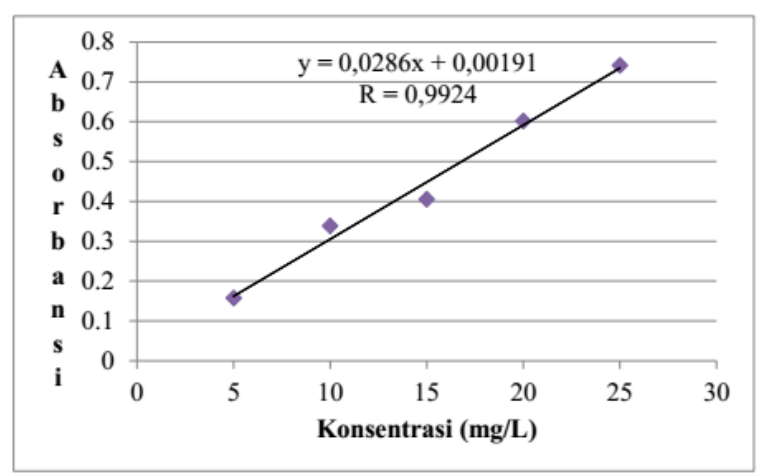

Gambar 2. Kurva Kalibrasi Larutan Standar Katekin

Penetapan kadar katekin diperoleh dengan dilakukan pengukuran absorbansi dari sampel. Hasil penelitian ditunjukkan pada tabel 3.

Tabel 3. Kadar Katekin Total Teh Hitam

\begin{tabular}{ll}
\hline Sampel & $\begin{array}{l}\text { Kadar Katekin total } \\
\mathbf{\%} \mathbf{b} / \mathbf{b}(\mathbf{m g} / \mathbf{g}) \pm \mathbf{S D}\end{array}$ \\
\hline SSDT & $15,30 \pm 0.22$ \\
SSBCA & $14,71 \pm 0.28$ \\
SDT & $8,37 \pm 0.13$ \\
SBCA & $15,16 \pm 0.58$ \\
EADT & $37,45 \pm 0.74$ \\
EABCA & $35,66 \pm 0.89$ \\
\hline
\end{tabular}

Data pada tabel 3 menunjukkan bahwa kadar katekin dari daun teh segar sesuai dengan penelitian Balittri, 2013 yang menyatakan kadar katekin daun teh segar antara 13,5 - $31 \%$. Berdasarkan hasil penelitian kadar katekin pada serbuk teh hitam, penurunan kadar katekin terjadi pada serbuk teh hitam dari perkebunan DT. Penurunan kadar katekin dari bahan segar menjadi serbuk teh hitam terjadi sebesar 54,7 
$\%$. Hasil ini sesuai dengan penelitian Karori, et al, 2007 dalam Balittri, 2013 melaporkan bahwa penurunan kadar katekin pada teh hitam sebesar $57,70 \%$. Berbeda halnya dengan kadar katekin dari serbuk teh hitam dari perkebunan BCA tidak terdapat penurunan kadar katekin. Sedangkan menurut Balittri, 2013 penurunan kadar katekin adalah keharusan karena terbentuknya theaflavin dan thearubigin memberi cita rasa khas pada teh hitam. Hasil penelitian tabel 3 juga menunjukkan bahwa pelarut aseton mampu menyari kadar katekin ekstrak DT dan BCA sebesar 36 - 37\%.

Informasi yang kurang pada penelitian ini adalah bagaimana metode pengolahan teh hitam yang dilakukan oleh masing - masing perkebunan karena terbatasnya informasi dari pengusaha perkebunan. Penurunan kadar katekin dari teh hitam biasanya terjadi paling besar pada tahap penggilingan dan oksimatis. Menurut Direktorat Pengolahan Dan Pemasaran Hasil Perkebunan, 2017 produk teh hitam berdasarkan pengolahannya dibedakan menjadi teh hitam ortodoks dan teh hitam Crushing-Tearing-Curling (CTC). Pengolahan keduanya berbeda pada penggunaan mesing penggilingan dan mesin oksimatis (terjadinya oksidasi enzimatis). Mesin penggilingan pada sistem ortodoks adalah menggunakan Open Top Roller (OTR), Rotorvane (RV) dan Press Cup Roller (PCR), sedangkan pada teh hitam CTC adalah sistem penggilingan CrushingTearing-Curling (CTC). Proses oksimatis pada pengolahan teh hitam ortodoks dioptimalkan dengan cara menyimpan bubuk teh pada baki sampai dengan bubuk teh dianggap sudah optimal oksimatisnya. Sementara itu pada proses pengolahan teh hitam CTC, oksimatis dioptimalkan pada mesin Continuous Fermenting Machine (CFM). Proses penggilingan pada teh hitam ortodoks berlangsung selama 75 menit. Dan proses oksimatis teh ortodoks berlangsung selama 90 - 110 menit. Pada pengolahan teh hitam CTC proses penggilingan dan oksimatis berlangsung selama $\pm 80-85$ menit (Direktorat Pengolahan Dan Pemasaran Hasil Perkebunan, 2017). Perlu dilakukan penelitian lanjutan terkait bagaimana pengolahan teh hitam dari perkebunan DT dan BCA untuk menjamin manfaat kesehatan, kualitas warna, aroma, rasa teh hitam yang dihasilkan.

\section{SIMPULAN DAN SARAN}

\section{Simpulan}

Teh hitam dari perkebunan DT memiliki kadar fenol yang lebih tinggi. Selain itu teh hitam DT diduga memiliki kandungan theaflavin dan thearubigin lebih tinggi karena terjadi penurunan kadar katekin ketika diolah menjadi teh hitam. Pelarut aseton mampu menarik senyawa fenol sebesar $\pm 7 \%$ pada kedua serbuk daun, dan $36-37 \%$ pada kedua ekstrak teh hitam.

\section{Saran}

Perlu dilakukan penelitian lebih lanjut pengukuran kadar katekin total pada setiap tahapan pembuatan serbuk hitam di perkebunan BCA untuk kontrol kualitas dan jaminan terhadap penurunan kadar katekin yang belum didapatkan pada penelitian ini.

\section{UCAPAN TERIMA KASIH}

Penulis mengucapkan terima kasih kepada pihak - pihak yang telah ikut membantu terlaksananya penelitian ini.

\section{DAFTAR PUSTAKA}

Anjarsari, I.R.D. 2016. Katekin teh Indonesia: prospek dan manfaatnya. Jurnal Kultivasi. 15(2): 99-106.

Balittri, J.T. 2013. Kandungan Senyawa Kimia Pada Daun Teh (Camellia sinensis), Warta Penelitian dan Pengembangan Tanaman Industri., 19(3): 12-16.

Bambang, K. dan Suhartika, T. 1995. Potensi teh Indonesia ditinjau dari aspek kesehatan. Laporan Hasil Litbang Teknik Produksi dan Pasca Panen Teh dan Kina. 1994/1995.

Direktorat Pengolahan Dan Pemasaran Hasil Perkebunan. 2017., Pedoman Penanganan Pasca Panen Tanaman Teh, Direktorat Jenderal Perkebunan. Kementerian Pertanian., 22-29.

Drużyńska, B., Stępniewska, A., Wołosiak, R. 2007. The Influence Of Time And Type Of Solvent On Efficiency Of The Extraction Of Polyphenols From Green Tea And Antioxidant Properties Obtained Extracts. Acta Sci. Pol. Technol. Aliment. 6(1); 27-36 
Hilal, Y. and Engelhardt, U. 2007. Characterisation of white tea-comparison to green tea and black tea. J. verbr. Lebensm 2: 414-421.

Karori, S. M., Wachira, F. N., Wanyoko, J. K. and Ngure, R. M. 2007., Antioxidant capacity of different types of tea products. African Journal of Biotechnology, 6: 228796, dalam Balittri, J. T. 2013. Kandungan Senyawa Kimia Pada Daun Teh (Camellia sinensis). Warta Penelitian dan Pengembangan Tanaman Industri. 19(3): $12-16$.
Perva-Uzunalic, A., S`kerget, M., Knez, Z., Grüner, B. W. F. O. S. 2006. Extraction of active ingredients from green tea (Camellia sinensis): Extraction efficiency of major catechins and caffeine. Food Chemistry. 96: 597-605.

Whitehead and Temple. 1992. Rapid method for measuring thearubigins and theaflavins in black tea using $\mathrm{C} 18$ absorbent cartridges. Journal of the Science and Food Agriculture. 58:149-152 dalam Anjarsari, I. R. D. 2016. Katekin teh Indonesia: prospek dan manfaatnya. Jurnal Kultivasi. 15(2): 99-106. 